Www.jmscr.igmpublication.org

Impact Factor (SJIF): 6.379

Index Copernicus Value: 79.54

ISSN (e)-2347-176x ISSN (p) 2455-0450

crossrefDOI: https://dx.doi.org/10.18535/jmscr/v6i11.75

Journal Of Medical Science And Clinical Research

\title{
Evaluation of Appropriateness of Inhaled Drug Delivery Systems in COPD Patients
}

\author{
Authors \\ Dr U.C. Jha ${ }^{1}$, Dr Peyalee Sarkar ${ }^{2}$ \\ ${ }^{1}$ Associate Professor, Dept of Medicine, DMCH, Laheriasarai \\ ${ }^{2} 3^{\text {rd }}$ year P.G Resident, Dept of Medicine, DMCH, Laheriasarai
}

\begin{abstract}
Background: Chronic obstructive lung disease (COPD) is a growing health burden for India with a significant mortality of 102.3/1,00,000 and 6,740,000 DALYs out of world total of 27,756,000 DALYs; thus significantly affecting health related Quality of Life in the country. Corner stone of management is via local drug delivery through various inhaler devices and the appropriateness of the technique of use of the devices has direct effect on the dose of drug delivered and thereby on the effectiveness of the treatment.

Objective: Determining common errors in technique of using drug delivering inhaled devices; correcting them and educating patients about correct use of the same.

Method: An observational study on a subset of 200 informed outpatients (diagnosed COPD cases using inhalational devices) across a period of 2 months (15th August 2018-15th October 2018) in the OPD of Darbhanga medical college, Laheriasarai using a proforma for recording all patient details. Techniques (as given in the review of European respiratory society) were assessed based on interviews and observation by a single interviewer. Collected data were analysed using SPSS version 22.

Result: the study showed maximum faulty technique (considered even if one mistake in technique) with MDI (92.3\%) followed by Rotahalers (85.4\%), MDI with spacer (75.6\%) and the least being with nebulisers (68\%). Illiterate population had atleast one mistake in $96.6 \%$ of subjects while population with higher secondary level education had mistakes upto $42.2 \%$. Results also varied depending on the person teaching the correct use with only $6 \%$ self taught patients achieving perfect techniques.

Conclusion: Majority of patients using inhalational devices made one or more errors which can be reduced by simple methods of demonstrating to the patient the correct use as this minor effort can have huge implications in reducing the number of exacerbation episodes by improved drug delivery, thus improving patient management.
\end{abstract}

\section{Introduction}

According to WHO, Chronic obstructive pulmonary disease (COPD) is a lung disease characterized by chronic obstruction of lung airflow that interferes with normal breathing and is not fully reversible $(\mathrm{FEV} 1 / \mathrm{FVC}<0.7$ and post bronchodilator FEV1<0.8)
Chronic obstructive lung disease (COPD) is a growing health burden for India with a significant mortality of $102.3 / 1,00,000$ and $6,740,000$ DALYs out of world total of 27,756,000 DALYs; thus significantly affecting health related Quality of Life in the country (WHO Global Infobase Updated on 20th January 2011) 
The primary causes as very well known are Tobacco smoke (active and passive inhalation), occupational exposure, a very important cause being indoor air pollution amongst many others. Establishment of diagnosis is characteristically by spirometry

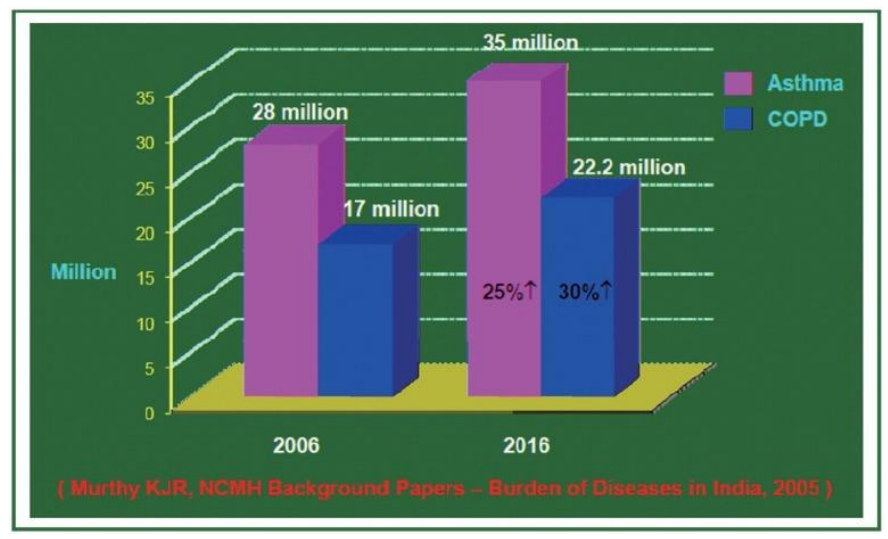

An effective COPD management plan includes four components: (1) assess and monitor disease; (2) reduce risk factors; (3) manage exacerbations (4) manage stable COPD.

The biggest challenge is posed in the management of stable COPD that is with the aim of preventing exacerbations and retarding the process of progression. The cornerstone of management is local (airway) drug delivery; bronchodilators and glucocorticoids (as and when required) by various inhalational devices (eg. MDI, Rotahalers, Nebulisers and the likes)

Poor handling of inhalational devices and wrong inhalational technique are associated with decreased drug delivery and poor disease control. The objective of this study was to evaluate and analyse technique of use of inhalational devices in
COPD patients as this has a humungous effect on the effectiveness of treatment administered and in reducing morbidity due to the disease.

\section{Methods and Materials}

An Observational study was conducted amongst diagnosed cases of COPD attending the outpatient department of Darbhanga medical college and hospital, Darbhanga in the age group of 40-70 (both extremes inclusive) over a period of 2 months; from 15th august 2018-15th October 2018.

A total of 200 patients were interviewed and observed after taking informed consent and were evaluated on the basis of a questionnaire prepared taking into account the sex, age, marital status, educational status, occupation, smoking habits, type of device used, educator regarding the device. Inhalational techniques were observed (while being used by the patient) and interpretations recorded. Data collected was analysed using SPSS version 22 .

Techniques of using 4 varieties of inhalational drug delivery systems were evaluated namely: 1) MDI (metred dose inhaler) 2) MDI with spacers 3) Rotahalers 4) Nebulisers.

The correctness of use of devices were interpreted according to the guidelines of the National Asthma Council Australia and European Respiratory Society.

The faults in their methods were identified and the accurate techniques were correctly demonstrated to the patient.

Results: Total Distribution of subjects using different drug delivery systems

\begin{tabular}{|l|c|c|c|c|c|}
\hline Variables & MDI users & $\begin{array}{c}\text { MDI with spa } \\
\text { cer }\end{array}$ & Rotahalers & Nebulisers & Total \\
\hline No.of patients & $80(40 \%)$ & $47(23.5 \%)$ & $52(26 \%)$ & $21(10.5 \%)$ & 200 \\
\hline $\begin{array}{l}\text { Sex: } \\
\text { a)male }\end{array}$ & $57(28.5 \%)$ & $36(18 \%)$ & $40(20 \%)$ & $11(5.5 \%)$ & $150(75 \%)$ \\
\hline b)female & $23(11.5 \%)$ & $11(5.5 \%)$ & $12(6 \%)$ & $10(5 \%)$ & $50(25 \%)$ \\
\hline $\begin{array}{l}\text { Education: } \\
\begin{array}{l}\text { a)>class 8 } \\
\text { b)<class 8 }\end{array}\end{array}$ & $33(16.5 \%)$ & $25(12.5 \%)$ & $19(9.5 \%)$ & $10(5 \%)$ & $87(43.5 \%)$ \\
\hline $\begin{array}{l}\text { Duration of use: } \\
<1 \text { year }\end{array}$ & $37(23.5 \%)$ & $22(11 \%)$ & $33(16.5 \%)$ & $11(5.5 \%)$ & $113(56.5 \%)$ \\
\hline 1-2 years & $21(10.5 \%)$ & $12(6 \%)$ & $10(5 \%)$ & $9(4.5 \%)$ & $52(26 \%)$ \\
\hline
\end{tabular}


Errors pertaining to individual drug delivery systems

\begin{tabular}{|l|c|c|c|c|}
\hline \multicolumn{1}{|c|}{ VARIABLES } & $\begin{array}{c}\text { MDI } \\
(\mathbf{8 0} \text { users) }\end{array}$ & $\begin{array}{c}\text { MDI with } \\
\text { spacer } \\
(\mathbf{4 7} \text { users) }\end{array}$ & $\begin{array}{c}\text { ROTAHALE } \\
\text { RS } \\
(\mathbf{5 2} \text { users) }\end{array}$ & $\begin{array}{c}\text { NEBULISE } \\
\text { RS } \\
(\mathbf{2 1} \text { users })\end{array}$ \\
\hline Not shaken inhaler & $48(60 \%)$ & $29(61.70 \%)$ & & \\
\hline Didn't exhale priorly & $42(52.50 \%)$ & $30(63.82 \%)$ & $27(51.92 \%)$ & $13(61.90 \%)$ \\
\hline Not inhaling quickly & & & $19(36.53 \%)$ & \\
\hline Poor seal around mouth & $29(36.25 \%)$ & $18(38.29 \%)$ & & \\
\hline Poor acceleration & & & $37(71.15 \%)$ & $16(76.19 \%)$ \\
\hline Puff inhalation incoordination & $50(62.5 \%)$ & $11(23.40 \%)$ & & \\
\hline Poor fitting of mask & & & & $8(38.09 \%)$ \\
\hline Improper dosing & $33(41.25 \%)$ & $16(34.04 \%)$ & $14(26.92)$ & $3(14.28 \%)$ \\
\hline
\end{tabular}

Errors per Influencing Factor

\begin{tabular}{|l|c|c|c|c|}
\hline VARIABLES & MDI & $\begin{array}{c}\text { MDI with } \\
\text { spacer }\end{array}$ & ROTAHALER & NEBULISER \\
\hline $\begin{array}{l}\text { Sex : } \\
\text { a)Male }\end{array}$ & $48 / 57(84.21 \%)$ & $25 / 36(69.4 \%)$ & $26 / 40(65 \%)$ & $8 / 11(72.7 \%)$ \\
\hline B) Female & $21 / 27(77.8 \%)$ & $5 / 11(45.5 \%)$ & $10 / 12(83.3 \%)$ & $8 / 10(80 \%)$ \\
\hline $\begin{array}{l}\text { Education: } \\
\text { a)>class 8 } \\
\text { B) < Class 8 }\end{array}$ & $25 / 33(75.8 \%)$ & $12 / 25(48 \%)$ & $9 / 19(47.3 \%)$ & $6 / 10(60 \%)$ \\
\hline $\begin{array}{l}\text { Educator: } \\
\text { a) Self }\end{array}$ & $44 / 47(93.6 \%)$ & $18 / 22(81.8 \%)$ & $28 / 33(84.84 \%)$ & $10 / 11(90.9 \%)$ \\
\hline $\begin{array}{l}\text { B) Physician } \\
\text { C) Pharmacist }\end{array}$ & $11 / 13(84.6 \%)$ & $10 / 12(83.3 \%)$ & $7 / 10(70 \%)$ & 0 \\
\hline Duration: a)<1 year & $35 / 41(85.7 \%)$ & $9 / 22(40.9 \%)$ & $14 / 20(70 \%)$ & $7 / 12(58.3 \%)$ \\
\hline b) 1-2years & $23 / 26(88.4 \%)$ & $11 / 13(84.6 \%)$ & $16 / 22(72.7 \%)$ & $9 / 9(100 \%)$ \\
\hline c) >2years & $16 / 37(89.2 \%)$ & $16 / 21(76.1 \%)$ & $9 / 13(69.2 \%)$ & $8 / 12(66.7 \%)$ \\
\hline
\end{tabular}

\section{Final findings}

1) Commonest used device is the MDI ( $40 \%$ of total users) and the least used being the nebulisers. Maximum errors were found amongst users of MDI (86.25\%) and least among users of MDI with spacer $(63.8 \%)$.

2)The commonest error committed by users was not exhaling completely prior to use of inhalational therapy (56\%), while very few people had improper mouth seal or mask fitting.

3)There was significant association $(p<0.05)$ between the educational status of the patients and the number of errors with less errors being committed by people with middle school level education.

4)Users of MDI with spacers showed significant association between the lesser number of errors if trained in use by physicians $(\mathrm{p}<0.01)$ enforcing the fact that physicians should ensure proper use of the devices.
5)The individual percentages of people committing errors were least in people using device for 1-2years while for people with $<1$ year or $>2$ years use showed increased errors signifying the importance of not only initial training but also in following up of patients.

\section{Discussion}

Even with the correct inhalational techniques only $20 \%$ of the drug (as per ERS) is delivered to the airways, rest being deposited in the oropharynx. Faulty techniques thereby hugely affect the efficacy of the drug delivery systems; increasing the number of exacerbations, hospital admissions and use of relievers and glucocorticoids and overall morbidity owing to the disease.

Physicians, Pharmacists, Nurses, Care givers should be properly acquainted with the correct technique of using a particular inhaled device.

The patients should not only be verbally explained about the techniques but should be demonstarted by the physician. The responsibility of ensuring 
that the patient understood also befalls on the physician.

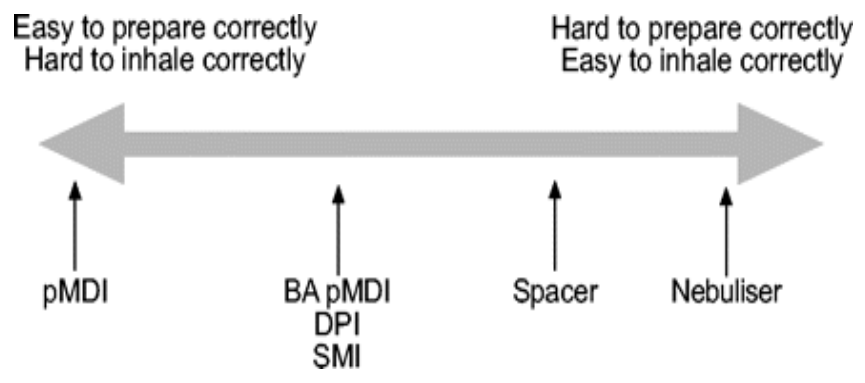

Both inhaler technique and adherence should be properly ensured before changing, adding on new drugs or increasing dosages because even people using these devices for more than a couple years actually tend to show increased number of errors. Hence regular follow ups are required even with patients who have been on treatment for some time. Although many pharmacological and non pharmacological interventions are available to prevent exacerbations and reduce morbidity of this disabling condition, the degree of reduction of exacerbation frequency by such interventions is still restricted, underlining the need for novel interventions to be developed and the proper utilisation of available ones which, just can't be stressed enough.

Interviews were conducted by a single interviewer trained in use of inhalational devices to eliminate interviewer bias.

However the study being based in a government setup in Darbhanga, causes a selection bias as the subjects enrolled mainly belong to the lower or lower middle socio economic strata of the society. Another limitation of the study was the non uniformity of the number of patients using each device.

\section{References}

1. Harrisons text boom of internal medicine $19^{\text {th }}$ edition

2. Respir Med. 2014 Jul;108(7):992-8. doi: 10.1016/j.rmed.2014.04.021. Epub 2014 May 14.Evaluating the technique of using inhalation device in COPD and bronchial asthma patients. Arora P1, Kumar
L2, Vohra V1, Sarin R1, Jaiswal A1, Puri MM1, Rathee D1, Chakraborty P1

3. Ther adv chronic disease, 2014 sept; 5(5):212-227 Chronic obstructive pulmonary disease exacerbations: latest evidence and clinical implications. Hammad Qureshi, Ami Sharafkhaneh, and Nicola A. Hanania

4. Respir Med. 2017 Feb;123:110-115. doi: 10.1016/j.rmed.2016.12.012. Epub 2016 Dec 21.How many instructions are required to correct inhalation errors in patients with asthma and chronic obstructive pulmonary disease? Takaku Y1, Kurashima K2, Ohta C2, Ishiguro T2, Kagiyama N2, Yanagisawa T2, Takayanagi N2..

5. J Manag Care Pharm. 2005 Jun;11(5 Suppl A):S2-13; quiz S14-6.Contemporary issues in the care of patients with chronic obstructive pulmonary disease. Urbano FL1, Pascual RM.

6. Respir Care. 2006 Feb;51(2):158-72. Practical problems with aerosol therapy in COPD. Rau JL

7. Health Technol Assess. 2001;5(26):1-149. Comparison of the effectiveness of inhaler devices in asthma and chronic obstructive airways disease: a systematic review of the literature. Brocklebank D1, Ram F, Wright J, Barry P, Cates C, Davies L, Douglas G, Muers M, Smith D, White J

8. European Respiratory Society Guidelines on the use of nebulizersJ. Boe, J.H.Dennis, B.R. O'Driscoll, T.T. Bauer, M. Carone, B. Dau tzenberg, P. Diot, K. Heslop, L. Lannefors European Respiratory Journal 2001 18: 228-242

9. Postgrad Med. 2018 Aug;130(6):515-522. doi: $\quad 10.1080 / 00325481.2018 .1481713$. Epub 2018 Jul 4.Clinical implications of the tiotropium/olodaterol inhaler for patients with chronic obstructive pulmonary disease.Ferguson GT1, Dalby RN2 
10. Int J Chron Obstruct Pulmon

Dis. 2009;4:381-90. Epub 2009 Oct 19.

Patient preferences for inhaler devices in

chronic obstructive pulmonary disease:

experience with Respimat Soft Mist

inhaler.Hodder R1, Price D 